\title{
Correlated Pollutants, Interregional Redistribution and Labor Attachment in a Federation
}

\author{
Naoto Aoyama • Emilson C. D. Silva
}

Published online: 5 February 2008

(C) Springer Science+Business Media B.V. 2008

\section{Erratum to: Environ Resource Econ DOI 10.1007/s10640-007-9183-7}

Due to a typesetting error the first author's name was incorrect. It should be Naoto Aoyama.

The online version of the original article can be found under doi:10.1007/s10640-007-9183-7.

N. Aoyama · E. C. D. Silva $(\varangle)$

School of Economics, Georgia Institute of Technology, Atlanta, GA 30332-0615, USA

e-mail: emilson@gatech.edu

\section{N. Aoyama}

S.K.K. Information Business college, 1-3 Tokuda, Hirosaki, Aomori 036-8032, Japan 